and thus elaborate thoughts, ideas, and feelings. In fine, the subject matter of the art and science of orthodontics is more than mere mechanics and malocclusion of the teeth. Dentofacial deformities constitute a large group of malformations due to errors of development, whose etiology, prognosis, pathological anatomy and pathological physiology are as yet very imperfectly understood. And though we revere the many contributions of the pioneers on this subject, we are not unmindful of present duties, or of the greater tasks in the future. All that has thus far been accomplished is but a faint beginning, a ray of light on the castern hills of the dawn.

(To be continued.)

\title{
HISTOLOGICAL STUDIES OF THE DEVELOPMENT OF THE CEMENTUM OF THE ROOT OF THE TOOTH OF YOUNG RHESUS MONKEYS
}

\author{
By F. Hecker, B.S., D.D.S., A.M., M.D., Kansas City, Mo. \\ Director of Research Laboratory of the Dewey School of Orthodontia, \\ Kansas City, Mo.
}

$\mathrm{O}^{\mathrm{N}}$ $\mathrm{N}$ making an examination of the literature relative to the origin of the cementum of the root of the tooth, we learn that the present teaching is that this tissue is laid down on the root of the tooth by the alveolar dental ligament. If the development of the cementum were dependent on the alveolar dental ligament, we would find in the substance of the fibrous capsule (which eventually becomes the alveolar dental ligament) in the immediate vicinity of its contact with the developing root of the tooth which it surrounds, cells or groups of cells which morphologically correspond to the cemental cells found in the apical area of the developing root in which the odontoblasts are commencing to arrange themselves. The alveolar dental ligament histologically is the same as the periosteum. The periosteum has by recent investigation been proved a limiting membrane for the growth of the bone; likewise, the author believes the alveolar dental ligament is a limiting membrane for the growth of the cementum. In a recent paper by the author, published in the International Journal of Orthodontia, Vol. II., No. 10, entitled, "Histological Studies of the Development of the Alveolus of Young Rhesus Monkeys," the present teaching that the development of the alveolus is dependent on the periosteum is not substantiated.

In this paper the author will endeavor to show that the cementum is not laid down on the root of the tooth by the fibrous capsule which surrounds the developing root of the tooth, but instead, that this tissue is laid down by the tooth pulp.

A study of slides made from the mandible and the maxillæ of young rhesus monkeys present microscopic evidence which does not coincide with the present teaching. But instead shows that cementum of the root of the tooth 
is laid down by the tooth pulp before the dentine is laid down. "lo present this evidence the author has made photomicrographs from the slides studied, which will be explained histologically.

Let us now commence a study of the photomicrographis. The first picture

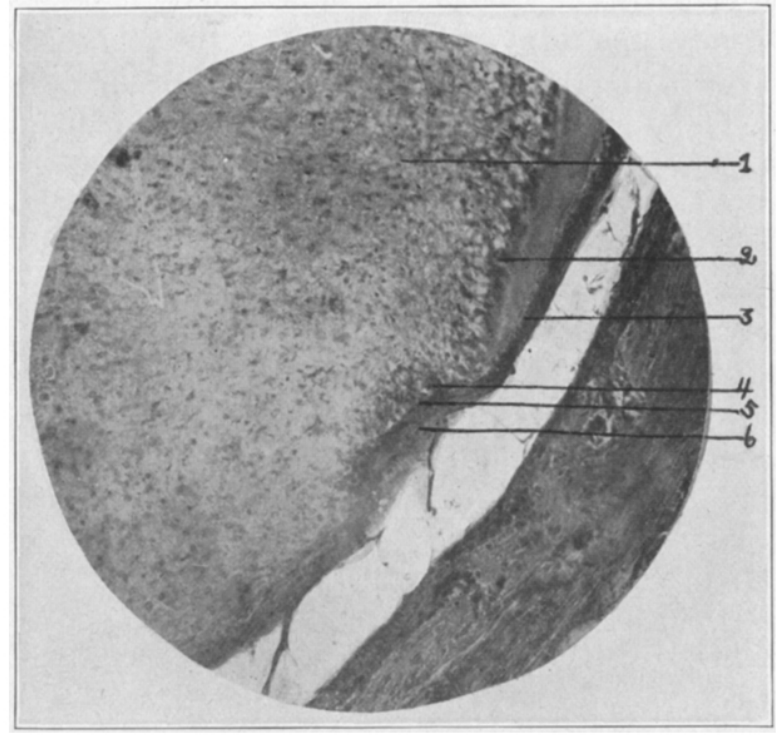

Fig. 1.-A low power ficture at the ancal area of the developing root of the young thests monkey

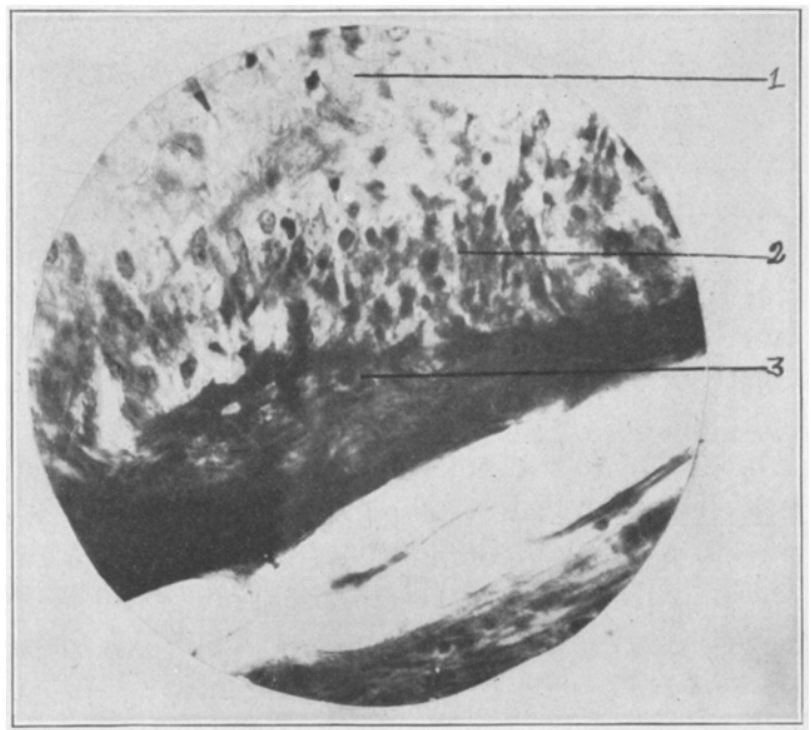

Fig. 2.-Showing a higher magnibection of an area in the same feld as Fige 1.

shown is the low magnification of the developing root near the apical area. Beginning at 1 , which is the tooth pulp of the developing root of the tooth, advancing to 2. we observe the odontoblast. At 3 is showis a space in which small cells are present. These cells are the cemental cells: continuing to 4 . 
we note that the dentine is now absent and that the odontoblasts are commencing to take their typical arrangement. At 5 is shown the cemental area. The cemental cells are faintly shown. Directly below 5 is shown the fibrous capsule, 6, which surrounds the developing root of the tooth.

The layer of cemental cells shown at 5 is termed by the author, the basel layer of the cementum, and it is from this layer that the future cemental lamellæ develop. The fibers of the fibrous capsule at this time of the development of the root of the tooth run parallel to it. If the cementum had its origin in the fibrous capsule there would be present in its substance in the immediate vicinity of its point of contact with the tooth, cells which morphologically are the same as the cells noted at 5 . The evidence presented by this picture refutes the present teaching, as to the origin of the cementum. The next picture (Fig. 2) is a higher magnification of an area in the same field as shown in

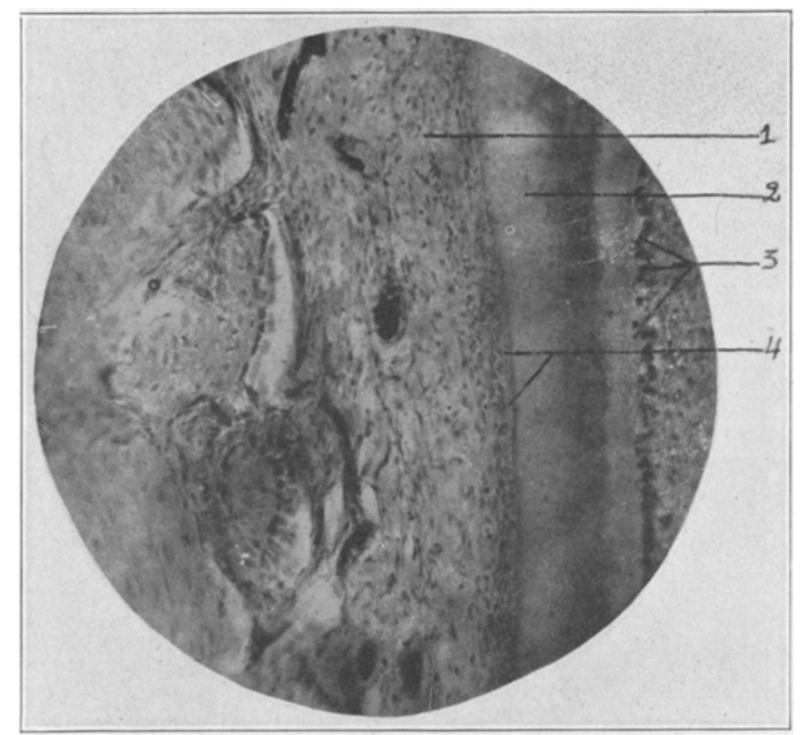

Fig. 3.-Low power magnification of the developing root near the point of bifurcation.

Fig. 1. Beginning at 1 , which is the tooth pulp, advance to 2 , at which point the odontoblasts are shown. Directly below the odontoblasts at 3 is shown the cemental area of the developing root of the tooth. The upper portion of the cemental area is very dense, this density being caused by the cemental cells.

Directly opposite the end of the pointing line for this area, one will, on careful examination, observe a cemental cell. Comparing the cell thus shown to the odontoblasts and mentally to the fibroblast, one finds that this cell morphologically does not correspond to either of the foregoing cells. Again we have evidence which does not coincide with the present teaching as to the origin of the cementum of the root of the tooth.

In the next picture (Fig. 3) is shown an area of a developing root a short distance below the point of bifurcation. At 1 is shown the fibrous capsule which surrounds the developing root of the tooth; at 2 , the dentine; at 3 , the odontoblasts; and at 4 , the cemental cells. Careful examination of the picture 
shows that the cemental cells are more numerous below the pointing line that above it. The cemental cells, although not shown in contrast are sharp enough in outline to be easily distinguished from the fibroblasts in the substance of the

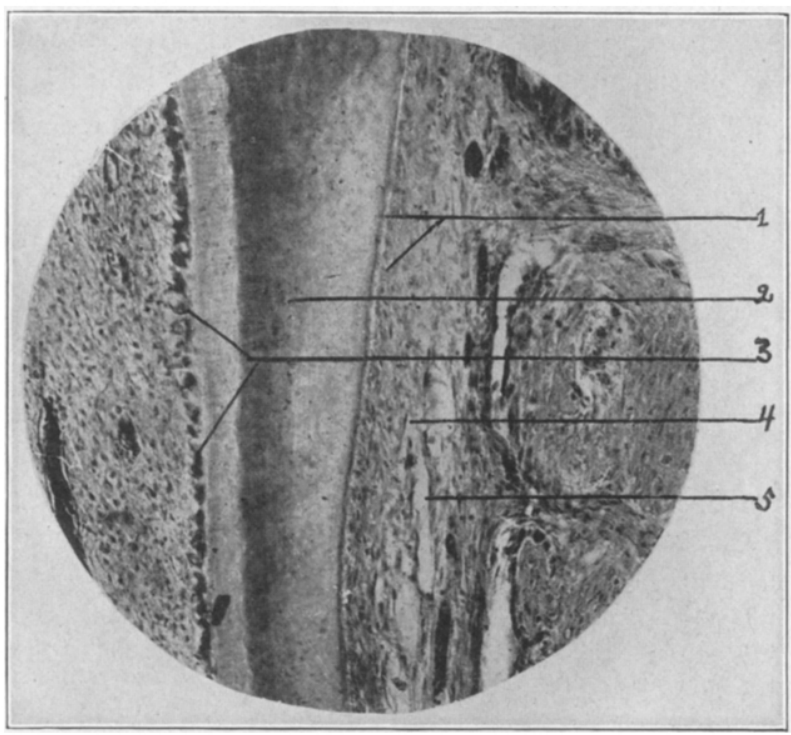

Fig. 4.-Showing a low magnification of the huccal surface midway between the apical and gingival areas

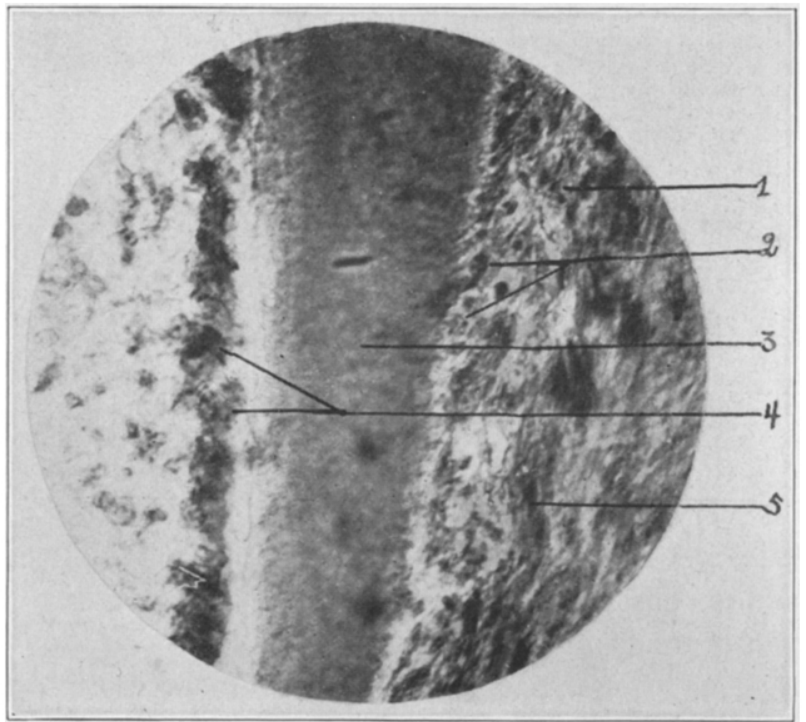

Fig. 5.- Showing a high magniacation of an area in the same field as Fig. 4

fibrous capsule. This picture shows that the cemental cells are not of a uniform size or shape but that they are laid down in layers or lamellæ at this time in the development of the root of the woth.

The fibers of the fibrons capsule in this picture do not show any attach- 
ment with the cementum of the root of the tooth. If the fibrous capsule were concerned in the development of the cementum, we would find in its substance in the immediate vicinity of its point of contact with the cemental area cells

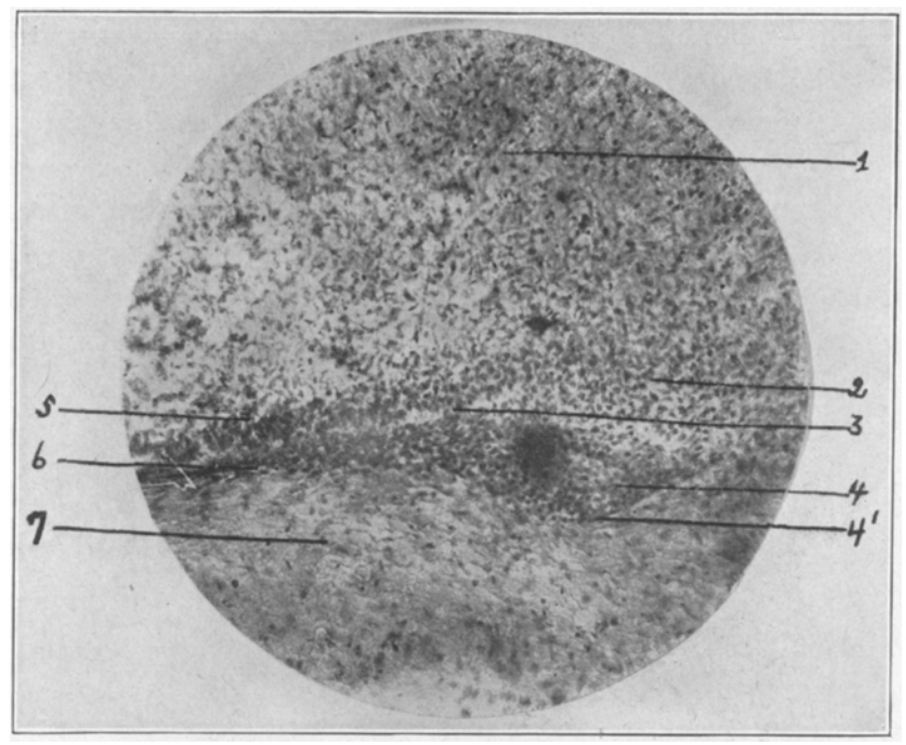

Fig. 6.- Showing a higher magnification of an area at the extreme apical portion of a developing root.

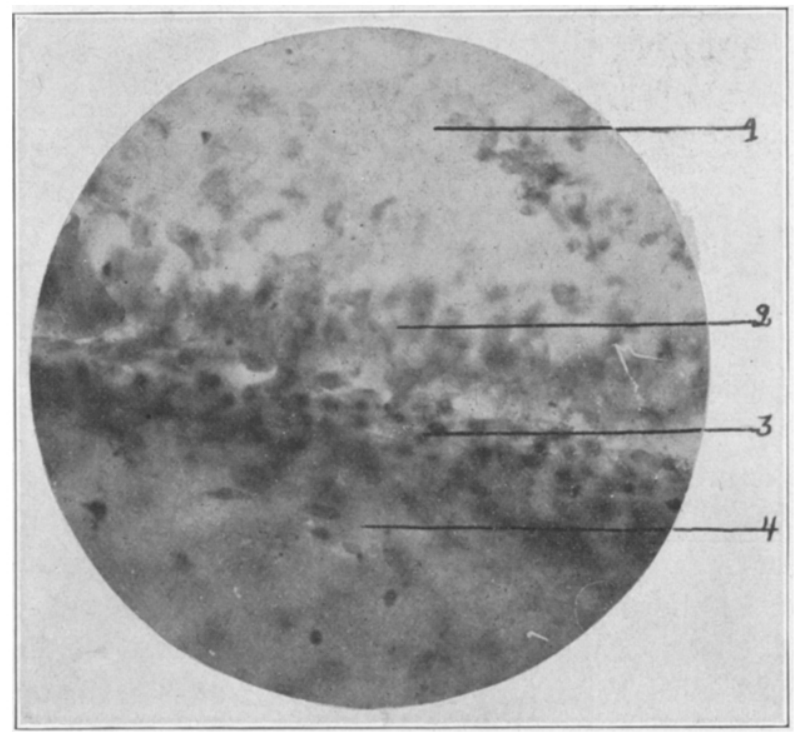

Fig. 7.--Showing a higher magnification of an area from the same field as shown in Fig. 6.

which morphologically correspond to the cemental cells found near the dentine. We would also find that some cells, cemental in type would be found between fibers which had partially attached themselves to the root of the tooth. The evidence presented by this picture is directly against the present teaching. 
The next picture (Fig. 4) is the bucal surface of the developing root of the tooth and is taken midway between the apical area and the gingival area. Beginning at 1 , we observe the cemental cells: their arrangement, not regular, nor are they uniform in shape and in size. Only one hyer of the cemental cells is shown in this picture. The reason that no more are showi is that no two layers are in the same platne when the fine adjustment of the microscope is employed. Hence the reason why only one layer or lamellae of cemental cells is shown.

At 2 is shown the dentine; at 3 , the montoblasts; and at 4 , the fibrove capsule which is cut longitudinally. In this picture we also observe that the fibers of the fibrous capsules are running parallel to the long axis of the developing root, no attachment of the fibers of the fibrous capsule being apparent.

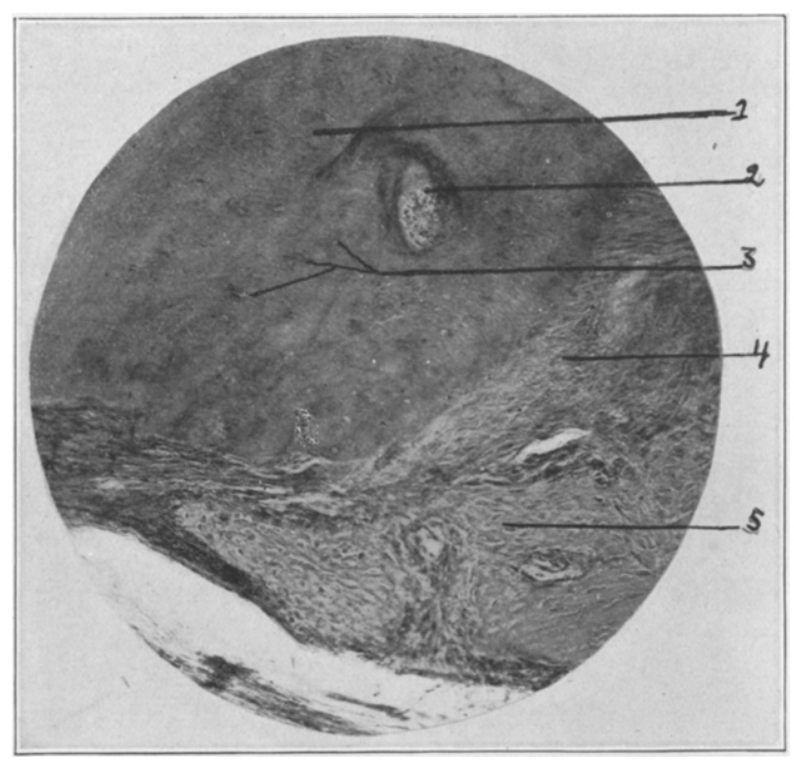

Fig. 8---Showing a canal in the substance of the cementum of the deciduous conth of the thestes monkey which the author believes is an Haversian canal.

The next picture (Fig. 5) is a higher magnification of an area of the same field as shown in Fig. 4. Beginning at 1 is shown the fibrous capsule; at 2 , the comental colls; and at 3 , the dentine. On careful examination of the cemental border of the dentine we note that it is very rough and irregular in outline, and that the cemental cells are in close contact with the dentine. Continuing towards 4 we note the odontoblasts, and at 5 is shown the fibroblasts of the fibrous capsule.

This picture shows that the general direction of the fibrous capsule surrounding the developing root of the tooth is parallel to the long axis of the root. In this picture we are offered an excellent opportunity to study morphology of the cementum cell and the fibroblast. The cemental cell, we observe, is round at this time of the development in the rout while the fibroblast is an elongated cell, the ends of which are tapered in a point, white the midnle of 
the cell is bulged. No apparent attachment of the fibers of the fibrous capsule to the root of the tooth is noticed.

The next picture (Fig. 6) is a low power picture taken from the extremc apical area of the developing root of the tooth. Beginning at 1 , which is the tooth pulp, and advancing to 2 , we at once notc that the cells in the area indicated by the pointing line show that they are commencing to take on the arrangement of the odontoblast. At 3 , the cells have now taken on a perpendicular position. At 4 , we note that the arrangement of the cells is not the same as observed at 3 , and further, that the cells are of a different kind than shown at 3. At 4 , we note that the cells have now taken on a definite arrangement which is in layers or lamellæ. Further study shows that the cells are morphologically different. The cemental cells being round while the odontoblasts are cylindrically shaped. One can by careful observation trace

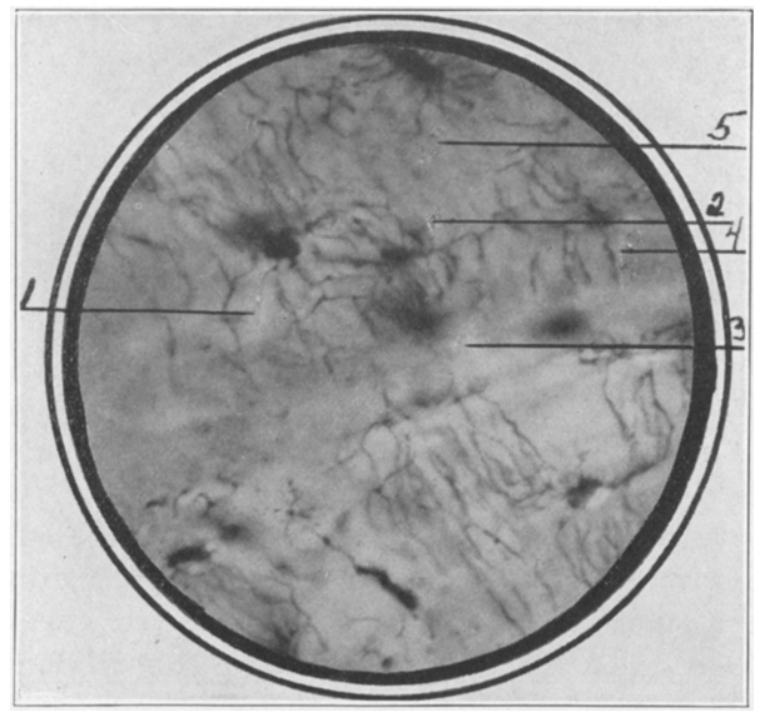

Fig. 9.- Showing lacunx and canalicula of bone.

the transitional changes in shape and position, the odontoblasts, and the cemental cells, if one begins at 3 and advances towards 5 for the odontoblasts, and from 4 to $4^{\prime}$ to 6 for the cemental cells. At 5 , are shown the odontoblasts and in this area they have taken their typical position. At 6 , we observe the lamellæ of the cementum, and on comparison, we learn that the cemental celis are round, while the odontoblasts are cylindrical in shape. At 7 , is shown the fibrous capsule which surrounds the developing root of the tooth. With this picture one is able to trace the transitional changes of the tooth pulp cell to the cemental cell and the odontoblast, and further one is able to show that the cemental cell is laid down before the odontoblast is at 4 and $4^{\prime}$, in which area the odontoblasts are just beginning to arrange themselves while the cemental show their position very distinctly.

The next picture (Fig. 7) is a high magnification of an area of the same field as shown by Fig. 6 . Beginning at 1 , which is the tooth pulp, advance to 
2, which shows the odontoblasts. At 3, is shown the cemental area in this area we observe that the cemental cells are laid down in lamellx. At 4 . is shown the fibrous capsule. In this picture we lave further evidence that the cementum of the root of the tooth is laid down by tooth pulp.

In the next photograph (Fig. 8) is shown an atea from the deciduous root in the rhesus monkey. The cementum of the root of the tooth is shown at 1 . At 2 is shown a canal in the substance of the cementum which has a definite circumscribed wall and around thi canal we find cemental bacunas, 3. The author has in his collection of slides a section from a human tooth in which there is also shown a canal in the substance of the cementurn. The question which now arises is: "Why is it that these canals are not contstantly fornd in the cementum?" The quetion can be answered as follows: In the process of embedding and placing the specimen to be cut, the angle of

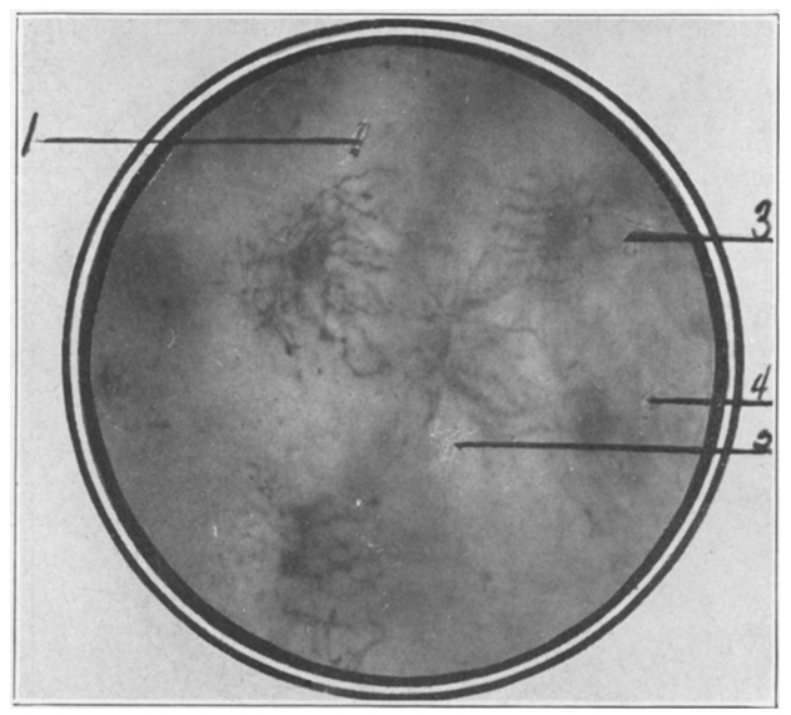

Fig. 10,-showing the lacume and candicule of the comentum.

the specimen is such that the canals contained in the cementum are not in the plane of the specimen and, therefore, are not found. One cannot deny that the canal shown in this picture is not a nutrient canal of the cementum. This being the case we are compelled to admit that the canal shown is an Haversian canal, and with this admission we are compelled to admit that the cementum found around the root of a tooth is true bone. At 4 is shown the alveolar dental ligament, and at 5 the alveolus.

Fig. 9 is shown a high magnification of bone showing the lacunæ and the canalicula. Careful examination of this picture shows that the lucane and canaliculæ, 1, 2, 3, 4, and 5, all communicate with each other.

Fig. 10 shows a highly magnified area of the cementum of the root of the tooth. In this picture it is clearly shown that the lacunæ and the canaliculæ of the cementum, 1, 2, 3, and 4 , all communicate with each other. Norphologically the cells of the cementum and of the bone are the same. 
The evidence thus presented by the foregoing photomicrographs does not coincide with the present teaching that the cementum is laid down on the root of the tooth by the alveolar dental ligament, but instead, proves that this limited bony covering is developed from the tooth pulp before the dentine is laid down. Further, this limited bony covering of the root of the tooth histologically at high magnifications shows that the lacunæ of the cementum and of the bone are morphologically the same, and that the bony covering of the root of the tooth is true bone because of the presence of a canal contained in its substance which the author believes is a nutrient canal and, therefore, an Haversian canal.

\title{
THE HISTORY OF ORTHODONTIA
}

\author{
By Bernhard Wolf Weinberger, D.D.S., New York City.
}

(Continued from page 5;1.)

$\boldsymbol{F}$. BAKER, in an article on "The Use of India Rubber in Regulating Teeth,"
. New York Dental Recorder, Sept., 1846, page 15, says:

"Apparently there is no portion of the human system, which is subject to so much irregularity and sometimes deformity, as the teeth.

"It would undoubtedly be interesting to search, if possible, into the arcana of nature, and trace by what phenomena, or laws of physiology, there is such a variety of classes of irregularity in this respect, or to consider what effect civilization has had in contributing to it. Irregularity of teeth rarely or never occurs in savage, or semi-civilized life,--so it may be said of the brute creation.

"There is frequently a disproportion between the aggregate size of the teeth and the capacity of the jaw for their regular accommodation. No doubt a contraction of the jaw may be produced by the frequent and injudicious practice of prematurely extracting the deciduous teeth of children.

"The age of twelve years is generally recommended as the proper time to rectify irregularities in the permanent teeth.

"Due care should be taken that the superior and inferior dental arches should be preserved in their proper relative positions. As a general rule, when there is irregularity in the upper, there also is in the under teeth, and the regulating of both may be accomplished at the same time.

"What are the best means for bringing irregular teeth into their desired position, when traction or force is necessary in order to accomplish it? In reasoning on the subject, the question will naturally occur,- what application to a tooth will be most likely (there being room) to bring it to the particular and desired position? The answer will be, that power which is so applied as to draw the tooth directly and continually towards the position you wish it to occupy.

"A very slight continued pressure will be sufficient to regulate the teeth of young persons while the processes are comparatively soft and yielding.

"Caoutchouc, elastic gum, or India rubber, is admirably calculated to produce the desired effect in regulating teeth.

"No substance is yet known which is so pliable and at the same time so 